\title{
Legal Procedure for Separation of the Child from his or her Parents: Inconsistency of Provisions of Russian Legislation with International Conventions
}

\author{
Olga Yuryevna llyina
}

Tver State University, 170000 Tver, Zhelyabova st., 33

Email: kinder_advokat@rambler.ru

\author{
Doi:10.5901/mjss.2015.v6n3s3p65
}

\begin{abstract}
The purpose of the study is detection of contradictions in the provisions of international conventions and Russian legislation, which regulates relations between parents and a child, who lives separately from them (one of parents); formulation and motivation of proposals regarding elimination of contradictions. The author studies subjective (based on parents' wishes) and objective (based on relevant government authority's decision) prerequisites for separate residence of the child and parents (one of parents) as an actual separation. Grounds and procedures, legal effects of separation of the child from his or her parents (one of parents) are stated and studied, potential conditions for restoration of co-residence and communication of the child with parents (one of parents) are studied. The provisions of family legislation regarding deprivation of paternal rights and restriction of paternal rights in the context of exercise of the child's power of communication with each of parents are criticized. The paper analyzes grounds, provided by the Family Code of the Russian Federation, for child and parents separation in terms of their consistency with requirements of The United Nations Convention on the Rights of the Child and the Hague Convention on the Civil Aspects of International Child Abduction. The neeed for taking into account child's opinion and consent when establishing the regime of communication with parents (one of parents) is stated. Objective need for juridical terminology enhancement is demonstrated: development of "parental custody", "right of access" and other notions. The need for amendments and additions in Russian legislation regarding provisions that enforce provisions of international acts in the area of child's and parents' rights protection is concluded.
\end{abstract}

Keywords: child, parents, power of communication, separation of the child from his or her parents, restriction of paternal rights, deprivation of paternal rights, international conventions.

\section{Introduction}

Upbringing, co-residence of the child and parents at least before attaining majority are considered by society a peculiar standard of relations. Corresponding social model is fully supported by legal format as parents' rights and obligations regarding child's upbringing, maintaining and education are established for the period of child's minority status (with limited exceptions, for example, in case of child's disability). Due exercise of parental rights and fulfillment of obligations are only possible providing child's continuous communication with his or her parents.

In case when the child and parents (one of parents) cannot live together for one reason or another, it's necessary to establish grounds for separate residence, present legal evaluation of the situation developed, observe regime establishment procedure for child's communication with each of parents for the purpose of ensuring child's and his or her parent's power of communication with each other. It's also important to take into account position, provided in clause 1 article 9 of the United Nations Convention on the Rights of the Child of 1989, that a child shall not be separated from his or her parents against their will, except when competent authorities subject to judicial review determine, in accordance with applicable law and procedures, that such separation is necessary for the best interests of the child.

Thus, in pursuance of the provisions of mentioned Conventions a Russian legislator should clearly establish grounds and procedure for child's separation from the parents, legal effects of the judgment delivered by a court or another competent government authority. Unfortunately, as shown in law enforcement practice materials and, particularly, judicial statistics, Russian courts often address this matter as a mere formality, thereby violating child's and his or her parents' rights (one of parents living separately from the child). Currently the problem of ensuring child's power of communication with one of parents within the framework of regime of communication of the child and his or her parent living separately established by court has become pressing (Practice review of disputes settlements by courts related to child-upbringing. Approved by the Presidium of Supreme Court of the RF, July 20, 2011).

The complexity of stated problem solution is also caused by the Russia's ratification of the Hague Convention on 
Civil Aspects of International Child Abduction 1980 (Federal law as of 31.05.2011 No. 102-\$3 "On the accession of the Russian Federation to the Hague Convention on the Civil Aspects of International Child Abduction"). One of the purposes of above-noted Convention is protection of children from the harmful effects of abduction and retention across international boundaries and providing a procedure to bring about their prompt return to the state of permanent residence and protection of access right as well.

It's also necessary to mention the Convention on Jurisdiction, Applicable Law, Recognition, Enforcement and Cooperation in Respect of Parental Responsibility and Measures for the Protection of Children, 1996 (Federal law as of 05.06.2012 № 62-Ф3 "On the accession of the Russian Federation to the Convention on Jurisdiction, Applicable Law, Recognition, Enforcement and Cooperation in Respect of Parental Responsibility and Measures for the Protection of Children). The very this Convention is of vital importance since the Hague Convention on the Civil Aspects of International Child Abduction lacks the mechanism of legal regulation concerning recognition and exercise of Russian Federation citizens' parental rights by foreign states (Khazova, 2014; Khazova, 2014(a). It is obvious that current legislation of the Russian Federation doesn't fully comply with the provisions of mentioned Conventions. Additions to the Civil Procedure Code of the RF pursuant to the provisions of above-mentioned Conventions have been already made there's special chapter 22.2 "Proceedings regarding examination of statements on the child' return or exercise of child' rights of access based on the international agreement of the Russian Federation". At the same time provisions of other branch legislation need improvement.

Tatarintseva E.A. has addressed obvious relevance of this matter: "However, according to clause "d", part 2, article 126 of the Criminal code of the RF, abduction of a child by his or her own parents, adoptive parents and equally close relatives against will of people who should raise him or her, is not considered a crime, if these actions are carried out in the child's best interests. Abduction of an own child by one of parents deprived of parental rights does not form components of crime provided by this article, that is doubtful to agree with" (Tatarintseva E.A., 2008). Correspondingly, bringing not only family but other branch legislation of the RF into conformity with the provisions of the above-mentioned Conventions is a top-priority task of the state. Ensuring child' interests is a key point that defines content and forms of legal regulations of relations in the area of child's communication with parents. Nonetheless, neither legislator nor executor of law does not provide the notion of "child's interests", which can be a universal one for any legal relationships involving a child. In respect to adoption relations the Plenum of the Supreme Court of the RF in the decree as of 20.04.2006 N8 "On the Legislation Application by Courts when proceeding cases of child adoption" (Rossiyskaya Gazeta, N 92, 03.05.2006) in clause 15 states: "When adopting children's interests should be particularly understood as creation of favourable conditions (both moral and material) for their upbringing and all-round development". There is theory of interest in the science of family law (llyina O.Y., 2007; Malinova, 2003), as well as special studies concerned with children's interests (llyina O.Y., 2006; Levushkin, 2013; Sholgina, 2011; Kovaleva, 2011). It stands to reason one must admit there are prerequisites for legal reinforcement of the "child's interests" notion in order to ensure enforcement of the provisions of international Conventions.

Moreover, Russian legislation lacks legal definitions of "right of custody", "right of access", "parental custody" and others; there are no clear regulations for the procedure of child's communication with parents disqualified or deprived of parental rights. As a consequence, bodies of trusteeship and guardianship or courts as competent authorities arrive at decisions, on the one hand, violate child's and parent's powers for communication with each other and, on the other hand, infringe the provisions of Conventions ratified by Russia.

It appears that for the purpose of development of effective mechanism for international conventions provisions enforcement it's possible to use corresponding positive foreign experience of regulation regarding children's interests intermediation in English-American law. According to Family Law Act 1996, necessary condition for issuance of separate residence or divorce decree is conclusion of agreement by spouses concerning children in the form prescribed by the court. The content of such agreements is thoroughly developed in accordance with The Family Procedure Rules (Tatarintseva E.A., 2004.). In 70's of the past century the conception of parent's joint custody of the child became widespread. One of parents who lives with the child has a right of so-called physical custody, whereas the other who lives separately, has a right of access, i.e. right to meet with the child at a certain time (Lyalina N.V., 2006).

Thus, need for prevention of actual violation of child's and his or her parent's power of communication with each other and non-fulfillment of the provisions of international documents determines relevance of the stated problem and proves the need for its theoretical apprehension, development and introduction of proposals regarding improvement of Russian legislation as related to meeting the requirements of The United Nations Convention on the Rights of the Child , 1989 and the Convention on the Civil Aspects of International Child Abduction, 1980 (Hague Conventions on Protection of Children in the Russian Federation. Application, enforcement and possible accession, 2013). 


\section{Literature Review}

The matters of actual separation of a child from parents (one of parents) are studied by the representatives of Russian science of family law through the prism of various aspects. Reasoning child's rights in such situation, Gromozdina M.V. makes an emphasis on the problem of legal interest intermediation of the child, exercise of parental rights in case the parents live apart (Gromozdina M.V., 2011). Tarusina N.N., addressing the topic of judicial discretion when settling legal family disputes, states that "the gulf of actual inequality between former spouse-parents expands" (Tarusina N.N., 2011), gender aspect is often disregarded when establishing regime of communication with a child. Many authors with good reason point out public interest in establishing regime of communication of a child and parents in case of actual separation. According to Sherstneva N.S, family education of a child is one of principles of family legislation, therefore separation of the child from his or her parents is only possible in cases and manner as prescribed by law (Sherstneva N.S, 2003). There's opposite point of view, Kumanovskaya A.L. notes that state is not a subject of parental legal relations, it only exercises the function of public supervision (Kumanovskaya A.L, 2005). It's also fair that many authors draw attention not only to the content of parental legal relationships but relationship of parents when interacting with a child (Zhigalin, S.S, 2004). Independent line of researches in this area is study of relation of voluntary (by parents' consent) and compulsory procedure for establishing regime of communication with a child. Heller M.V. fairly states that complexity is the need not only to agree on the regime but, what is more important, to determine child's place of residence (Heller M.V., 2006)

\section{Materials and Methods}

In the Russian Federation power for mutual communication is provided by the law for both child and his or her parent. A legislator dedicates several articles of the Family Code to corresponding provisions, recording belonging of respective law to named subjects, establishing grounds and procedure for the change of regime of communication and forms of separation of the child from parents (one pf parents).

Let's consider content of several articles of the FC of the RF from a perspective of ensuring the best interests of the child, equality of parents' rights for child upbringing and compliance of the provisions of Russian legislation with specified international Conventions.

1. Child's and his or her parent's power for communication can be provided by means of enforcement of the child's right to live and be raised in the family (art. 54 of the FC of the RF). Each child has a right to live and be raised in family, as far as possible, to know his or her parents, has right for their care, right to live together with them, except it is contrary to the child's best interests. Obviously, the child interacts with each parent when together lives with them.

However, according to art. 63 of the FC of the RF parents have right and are obliged to raise their children. Parents are responsible for upbringing and development of their children. They obliged to care for their children's health, physical, mental, spiritual, and moral development,

We agree that proper child's upbringing and ensuring his or her interests are only possible when the child and the parents communicate, i.e. all the time. Therefore, there is every reason to believe that it is power for communication that defines conditions for the exercise of all the rest parental rights and obligations.

Given this, it's necessary to properly define the content of this law - it is mutual since the child has power of communication with each of the parents, and each of parents, correspondingly, has power of communication with the child.

Tarusina N.N. states "in case of actual separate residence all parental legal powers are exercised, except protective power regarding protection of parental rights, and that actual separate residence as socially valuable phenomenon requires special legal regulation - both in general and by its types" (Tarusina N.N., 1999).

2. At the same time, there are certain complications when child's parents are not married and for this reason live apart, or parents divorced or court declared parents' marriage invalid. The latter case is more complicate since the child has already lived together with his or her parent, but regime of communication with parents (one of parents) is changed pursuant to judicial decision of divorce or invalid marriage.

According to clause 1 art. 55 of the FC of the RF, dissolution of parents' marriage, avoidance of the marriage or initial separate living of parents do not influence child's rights. Certainly, child's power for communication with each of parents is reserved, but enforcement of the right is changed.

As a rule, actual separation of a child with one of his or her parents should have different prerequisites: initial 
separate residence of parents or marriage dissolution. It should be noted that emergent legal relationships regarding upbringing of the child are relatively completely specified by the provisions of the FC of the RF.

At the same time, relations emergent as consequences of annulment of marriage are not regulated at all. Bespalov A.Y. fairly states that when a marriage is annulled, a child loses possibility to live and be raised in two-parent family, right for living together with two parents, right for upbringing by both parents (Bespalov A.Y., 2011). Thus, there is the objective need for regulation of relations between child and parents, whose marriage was declared invalid.

3. Family legislation establishes particular regime of parental rights exercise by a parent, who lives apart from his or her child. In accordance with clause 1 art. 66 of the FC of the RF, a parent, who lives apart from his or her child, has power for communication with the child, right to take part in his or her upbringing. A parent, with whom the child lives, should not prevent child's communication with another parent, unless such communication harms child's physical and mental health, his of her moral development.

Taking into account above-mentioned statement the following should be noted: if a parent with whom the child lives, puts obstacles in communication of the child and a parent, who lives apart from his or her child, he or she actually separates them. Moreover, this act should be classified as infringement of the rights of communication of the child and the parent who lives apart. Obviously, obstacles in communication can be caused by external circumstances, for example, by culpable conduct of the parent who lives apart. In this case the notion of "child's interests" become especially relevant, since establishing of the regime of communication of the child with each of parents depends on it. It is also possible that the parent who lives together with the child may lack conscientiousness, since separation of the child and another parent can be resulting from corresponding breach of law.

Thus Russian legislation established the order of mutual communication of the child and each of parents even if one of them lives apart (Gromozdina M.V, 2010).

The distinguishing characteristic of Russian legislation is that parents are empowered to voluntarily settle all issues regarding exercise of power for mutual communication. Parents have a right to conclude an agreement in written form for procedure for exercising parental rights by a parent, who lives apart from his or her child (clause 2 art. 66 of the FC of the RF). If parents fail to agree upon corresponding matter, dispute is settled at court with the participation of tutorship and guardianship authority.

Special explanations for legislative execution when establishing procedure for child's communication with each of parent are included in Decree of the Plenum of the Supreme Court of the Russian Federation as of May 27, 1998 No.10 "On the Legislation Application by Courts when proceeding cases of child-upbringing" (Bulletin of the Supreme Court of the Russian Federation, No.7, 1998). Clause 4 of this decree particularly states that in case of taking a decision of divorce of spouses who have minor children in common, the court explains to the parties that a parent, who lives separately, has a right and is obliged to take part in upbringing of the child, and the parent with whom the minor lives, shall not impede to it.

The regime of exercising the power of mutual communication is largely defined by fixing child's place of residence. It should be emphasized if parents do not agree upon the matter, it's settled in the court. Herewith place of residence of the child is determined based on his or her interests, and taking into account the opinion of the child aged ten, except it is contrary to the child's interests (clause 3, art. 65, 67 of the FC of the RF).

Disputes regarding child's place of residence and the procedure of exercising parental rights by a parent, who lives separately from the child, consist considerable part of cases examined by judges. Once again it's necessary to emphasize incompleteness of Russian legislation, particularly, when ruling jurisdiction of mentioned disputes. We consider Maksimovich's statement regarding proper court decision concerning the content of dispute over children and ensuring of interests of the latter when proceeding divorce cases, fair (Maksimovich L.B., 2014).

It's quite obvious that child's interests, particularly his or her communication need and wish to interact, should be a criterion in judicial settlement of disputes relating to exercising power for communication of each of parents with the child. According to Tekeeva A.l., legal representatives are closer to rights' holders, whose interests they represent, i.e. to the child (Tekeeva A.I., 2003). This raises the question of who of the parents understands child's interests better. It's possible to suggest it's the parent with whom the child lives together. However, in our opinion, the situation may change since the notion of "child's interests" shouldn't be considered a stable category.

It's necessary to address art. 57 of the FC of the RF, which defines general rules of exercising child's right to express his or her opinion. It's stated that the child has a right to express his or her opinion when solving in the 
family any issue that affects his or her interests, and also be granted a hearing in the course of any court or administrative proceedings.

It means when discussing issue of place of residence with one of parents, the child should be provided with an opportunity to express his or her opinion. However, it doesn't mean that decision will be made by a tutorship and guardianship authority or court in accordance with child's given opinion. His or her opinion will be taken into account, but the opposite decision may be made.

In the same article a legislator put an emphasis on the following: it's necessary to take into account the opinion of the child aged ten except it is contrary to his or her interests. Consequently, the child's opinion should be not only heard but formally considered. If the decision is made by a tutorship and guardianship authority or a court, child's opinion and made decision should be recorded in minutes of proceedings, it should be specified why the decision corresponds or doesn't correspond to the opinion of the child aged ten. Criteria are the same: child's interests, adverse actions to which can become ground for taking a decision, which doesn't correspond to the child's opinion.

Finally, a legislator specifies that in cases explicitly provided by the law a tutorship and guardianship authority or a court can made a decision only with the consent of the child aged ten. What is important, disputes relating to determination of child's place of residence and establishing of regime of communication with the parents in case of actual separation of the child from one of them aren't mentioned in the corresponding provisions. It turns out that existing in the field of law enforcement wrong belief regarding obligatory determination of the consent of the child over ten years to live with one of parents has no legal basis.

4. The above-mentioned facts are indicative of actual separation of the child from one of parents, herewith formal decision of corresponding matter is determined by parent's (one of parents) will and wish.

Let's refer to art. 69 of the United Nations Convention on the Rights of the Child, which prescribes the order of child's separation with parents (one of them). Making a decision to separate the child's from his or her parents can be objective decision in one or another specific case, for example, when the parents abuse their child or do not care for him or her, or when the parents live apart and it's necessary to make a decision regarding the child's place of residence.

Separation of parents is possible, when they are deprived of parental rights under the court decision. In conformity with the law deprivation of paternal rights means deprivation of all parent's rights, based on the blood relation with the child, but it doesn't release them from responsibilities regarding child support. It should be noted that a legislator nevertheless presumes possibility of restoration of legal relations between the child and his or her parents deprived of parental rights.

It represents particularity of separation, a legislator presumes possibility of restoration of parental rights by parents based on child's interests.

According to art. 74 of the FC of the RF, a court may deliver this judgement, if the child isn't adopted yet. It's important to take into account that a court shall dismiss allowance of parents' claim, if the child over ten years is against it. It's necessary to mention interpretations of the Plenum of the Supreme Court of the Russian Federation: court shall not sustain a claim irrespective of the child's motives of denial in restoration of parental rights (clause 19) (Decree of the Plenum of the Supreme Court of the Russian Federation as of as of May 27, 1998 No.10 "On the Legislation Application by Courts when proceeding cases of child-upbringing" (Bulletin of the Supreme Court of the Russian Federation, No.7, 1998).

Thus in this case a child aged ten decides by himself or herself whether not only rebuild relations with parents, but restore legal relations with them at all.

As distinct from former legislation, current FC of the RF shall not allow parents deprived of parental rights to communicate with their child, that establish the identity of formal and actual separation of the child of parents deprived of parental rights.

5. In case of judicial decision of parents' restriction in parental rights (art. 73 of the FC of the RF), the child is also separated from them, but other legal consequences, particularly, in the area of communication appear. According to art. 75 of the FC of the RF, parents, whose parental rights were abridged by a court, may be allowed to interact with their child, except it adversely affects the child. Parents' contacts with their child are permitted with the consent of a tutorship and guardianship authority or guardian, foster parents of the child or organization, where the child stays. Consequently, in this case the regime of communication of the child and his or her parents is established by the tutorship and guardianship authority or individuals, who raise the child. It means the separation of the child from parents is determined by the decision of third parties in compliance with a court order regarding parents' rights restriction (Ordinartsev I.I., 2012). 
However, it's important to specify opportunity for the communication of the child and his or her parents abridged in parental rights in corresponding decision of the court. Otherwise, nether tutorship and guardianship authority nor other individuals, who raise the child, shall not allow him or her to communication with his or her parents (one of parents), since they cannot change the decision of the court. Given parental rights restriction subject to non-culpable behaviour of parents, duration of separation can be initially specified by a notice, for example, as of the day of parent's recovery. If abridging parental rights is used by the court as a measure before the following deprivation of paternal rights, communication of the child with his or he parents is not to be restored, if the court eventually considers the case of deprivation of paternal rights.

6. It should be emphasized that a child, whose parents live in different countries, has a right to maintain personal relations and direct contacts with both parents on a regular basis, except for specific circumstances (art. 10 of the UN Convention of the Rights of the Child). For this purpose participant-states respect child's and parents' right to leave any country, including their own country, and come back to their country.

In relation to the right of any country leaving only restrictions are effective, which established by the law to provide national security, public peace, health or morals of population or rights and freedoms of others individuals, and that are consistent with the rights provided by the Convention. According to art. 11 of the Convention, participant-states take measures to struggle unauthorized movements and non-return of children from abroad. As mentioned above, in pursuance of the provisions of the Convention on Civil Aspects of International Child Abduction, special chapter 22.1 was introduced to the Procedure Code of the RF. it provides the mechanism of proceedings in cases relating to return of kidnapped children and children unlawfully retained.

\section{Results and Discussion}

Thus, Russian legislation provides several procedures of separation of the child from his or her parents, based on various grounds and criteria. In particular, the following is taken into account.

1. Marriage state of child's parents. A legislator establishes different regime for grounds and procedure for regulation of separation from one of parents, depending on following circumstances: child's parents are married or separation is caused by divorce procedure; child's parents are not married and have never been married to each other; child's parents are married, but live apart; child's parents were married, but their marriage has been declared invalid. At the same time a legislator expresses imperative precept - the scope of child's rights is identical, therefore, he or she has power for communication with each parent in any mentioned case. Parents' marriage status only influences the procedure for establishing and directly regime of communication of the child with his or her parents.

2. Subjective and objective preconditions of separation of the child from one of parents. A legislator provides various grounds based on the following prerequisites: will or wish of parents or decision of government agency of Russian Federation entity or local government body for removal of a child from custody in case of imminent danger to child's life or health or court in case of abridging (deprivation) parental rights. Depending on this parents' agreement concerning communication of the child with one of them can be drawn up in written form, can be notarized, otherwise, this procedure is established in the decision of a tutorship and guardianship authority or a court.

3. Child's place of residence and his communication with his or her parents (one of them who lives separately) can be determined by parent's agreement, which can be certified by a notary at their will, or by decision of the court. In this case the parents additionally agree upon the question of the child's residence, that matters when each of parents exercises powers of legal interest intermediation of the child.

4. Age of the child. In particular, whether the child is of ten years, since in this case his or her opinion shall be taken into account when settling corresponding issues, except it conflicts with his or her interests. When making agreement for the order of child's communication with each of parents in case of actual separation from one of them it's important to take into account period, for which corresponding regime of communication is established. As the child grows up and attains years relevant in law, the agreement should be changed. In particular, the regime of communication of a child, who attends pre-school educational institution, and the regime of communication of a child - pupil of senior school should be different. Parents can change formerly concluded agreement. As for decision of the court, established order can also be changed by court upon the application of interested party. 


\section{Conclusions}

Specific of the procedure for separation of the child from his or her parents (one of them), established by international acts, are explained by the earlier adoption of the Convention on Civil Aspects of International Child Abduction than The United Nations Convention on the Rights of the Child, but ratified by the Russian Federation much later. Owing to it Russian legislation doesn't meet requirements of above-mentioned documents to the full.

In this regard there is objective need for bringing provisions of the Family Code of the RF to conformity with requirements of the ratified international act, particularly, The United Nations Convention on the Rights of the Child, the Hague Convention on Civil Aspects of International Child Abduction, and the Convention on Jurisdiction, Applicable Law, Recognition, Enforcement and Cooperation in Respect of Parental Responsibility and Measures for the Protection of Children with regard to regulation of grounds, procedure for decision-making and specifics of legal effects of separation of the child with his or her parents.

Above-mentioned statements can be used as theoretical basis for the development of Russian legislation enhancement concept regulating relations in the area of the child's communication with parents (one of parents) in case of actual separation. However, the research cannot be deemed full because of the lack of projects of criminal and procedural Russian legislation reforming. It's also difficult to suppose possible trends of law enforcement practice formation: there is an objective need for development and approval of criteria for settling corresponding disputes by tutorship and guardianship authorities and court. In this context the author's statements are considered an invitation to scholarly dispute and may promote further academic pursuits in the given area.

\section{Acknowledgements}

The author expresses her appreciation to candidate of legal sciences, associate professor Khazova Olga Aleksandrovna, a representative of the Russian Federation in the UN CRC Committee for provided materials and their official interpretation; to candidate of legal sciences, associate professor Tatarintseva Elena Aleksandrovna - a specialist in the area of foreign legislation regarding rights of the child in family, and also to Chairman of Moscow city court Egorova Olga Aleksandrovna for provided judicial practice materials on the studied matter.

\section{References}

Bespalov, A.Y. (2011). Invalidity of marriage in the Russian Federation. Some substantive and processual legal aspects. Monography. Moscow: UNITI-DANA: Zakon i pravo.

Decree of the Plenum of the Supreme Court of the Russian Federation as of May 27, 1998 No.10 "On the Legislation Application by Courts when proceeding cases of child-upbringing".

Decree of the Plenum of the Supreme Court of the Russian Federation as of 20.04.2006 N8 (edited as of 17.12.2013) "On the Legislation Application by Courts when proceeding cases of child adoption". Rossiyskaya Gazeta, N 92, 03.05.2006.

Federal law as of 05.06.2012 No.62-\$3 "On the accession of the Russian Federation to the Convention on Jurisdiction, Applicable Law, Recognition, Enforcement and Cooperation in Respect of Parental Responsibility and Measures for the Protection of Children. The "Konsultantplyus" reference legal system.

Federal law as of 31.05.2011 No. 102- $\$ 3$ "On the accession of the Russian Federation to the Hague Convention on the Civil Aspects of International Child Abduction". Rossiyskaya Gazeta, No.119, 03.06.2011.

Gromozdina, M.V. Exercise of parental rights in case of parent' separate residence according to legislation of the Russian Federation: Thesis of candidate of legal sciences. Moscow, 2010.

Gromozdina, M.V. Exercise of parental rights in case of parent' separate residence according to legislation of the Russian Federation. Monography. Novosibirsk, 2011.

Heller, M.V. Extrajudicial procedure of protection of minor's rights to live and be raised in family in modern Russian legislation. Family and housing law. 2006. N 2.

Ilyina, O.Y. (2006). Child's interests in family law of the Russian Federation. Monography. Moscow: the "Gorodets" Publishing House.

Ilyina, O.Y. (2007). Child's interests in family law of the Russian Federation. Monography. Moscow: the "Gorodets" Publishing House.

Khazova, O. (2014) The first year Application of the Hague 1996 Convention on Protection of Children in Russia: success story. International Family Law, London, No. 3. pp. 165-169.

Khazova, O. (2014). Russia's Accession to the Hague Convention on Civil Aspects of International Child Abduction 1980: New Challenges for Family Law and Practice // Family Law Quarterly (ABA, USA), 2014, Summer issue).

Kovaleva, M.L. (2011). Priority rights in family law of the Russian Federation. Synopsis of the thesis of candidate of legal sciences. Moscow.

Kumanovskaya, A.L. (2005). Parents' rights and responsibilities regarding child-upbringing in family law of the Russian Federation. Thesis of candidate of legal sciences. Moscow. 
Levushkin, A.N. (2013). Theoretical model of family legislation system construction of the Russian Federation and other CIS countries. Synopsis of the thesis of doctor of legal sciences. Moscow.

Lyalina, N.V. (2006). Content, exercise and protection of rights of a parent, who lives apart from a child, in the Russian Federation and the United States of America. Thesis of candidate of legal sciences. Moscow.

Maksimovich, L.B. (2014). Divorce complicated with a dispute over children: processual aspect. Tver State University Herald. "Pravo" series, No.2, pp. 198-199.

Malinova, A.G. (2003). The "interest" category in family law. Synopsis of the thesis of candidate of legal sciences. Ekaterinburg.

Practice review of disputes settlements by courts related to child-upbringing (approved by the Presidium of Supreme Court of the RF, July 20, 2011).

Sherstneva, N.S. (2003). Principles of family law ensuring minor children' rights and interests. Tver.

Sholgina, O.I. (2011). Child's interests as a matter of family legal dispute. Synopsis of the thesis of candidate of legal sciences. Moscow.

Tarusina, N.N. (1999). Outline of Russian family law theory. Yaroslavl.

Tarusina, N.N. (2011). Concerning judicial discretion. Monography. Yaroslavl.

Tatarintseva, E.A. (2004). Parents' responsibility in accordance with family legislation of Russia and England. Synopsis of the thesis of candidate of legal sciences. Moscow.

Tatarintseva, E.A. (2008). Parents' responsibility in accordance with family legislation of Russia and England (comparative law analysis). Tver: Tver State University.

Tekeev, A.I. (2003) Theory and practice issues of investigation and judicial decisions of civil cases with the participation of a child. Synopsis of the thesis of candidate of legal sciences. Saratov.

The Convention on Civil Aspects of International Child Abduction 1980: New Challenges for Family Law and Practice. Family Law Quarterly (ABA, USA), 2014, Summer issue.

The Hague Conventions on Protection of Children in the Russian Federation (2013). Application, enforcement and possible accession. Moscow: "Tsentr YurlnfoR" JSC.

Zhigalin, S.S. (2004). Formation of adequate parental positions as educational process correction technique of juveniles' family. Synopsis of the thesis of candidate of legal sciences. Ekaterinburg. 